\title{
Olympiodorus and Damascius on the Philosopher's Practice of Dying in Plato's Phaedo
}

\section{MELINA G. MOUZALA / Patras /}

The aim of this paper is to trace the relations and distinctions between certain notions that emerge in the first section of Plato's Phaedo, such as death, the philosopher's practice of dying, purification, and separation (chōrismos) of the soul from the body, based on the Neoplatonic commentaries of Olympiodorus and Damascius. According to Olympiodorus' commentary ${ }^{1}$ there are two main points at issue in this first section of Plato's Phaedo (61 c 2-69 e 4): one, that the philosopher is not permitted to take his own life, the other that the philosopher is willing and ready to die. The second, that the philosopher will face death without fear and will prepare for it, has been proved by Socrates in his Apologia (Defence), passage 63 b 1-69 e 4.

1 All references to the text of Olympiodorus' Commentary on the Phaedo are from Westerink (2009). See Olympiodorus, 3, $\$ 1,2-6$. Cf. Olympiodorus, $1, \$ 12,3-4$. 


\section{The dual meaning of death (thanatos)}

Olympiodorus draws a very clear-cut distinction between the pursuit of death and the readiness to die. These are two different things and this distinction has to be associated with the dual meaning of death. Given that there is on the one hand the bodily or physical death, and on the other the "voluntary" (or philosophical) death, i.e. detachment from affects, Olympiodorus ${ }^{2}$ states that where "voluntary" death is concerned the philosopher both pursues death and is ready for it, but where bodily death is concerned, there is only readiness, not pursuit. In this way Olympiodorus' interpretation clarifies that the philosopher's will and readiness to die is associated with both kinds of death, whereas the philosopher's preparation for death in the sense of pursuit of it is not. This means that the philosopher does not strive to reach the state of bodily death, although he is ready for it.

The dual meaning of death (thanatos) is also reflected in the terminology of the ancient Greek text, where Plato-Socrates uses two different infinitives, apothnēskein (dying) and tethnanai (being dead). ${ }^{3}$ Apothnesskein means "to die", and this infinitive can denote either the event, i.e. death as an incident, death as an occurrence, as an instantaneous affair, or the process of dying, i.e. death as a lasting undertaking and continuous experience. This second meaning is most suitable in the case where apothneskein indicates the "voluntary" death. Tethnanai means being dead, the state of being dead which comes after death. The two infinitives and the relative terms predominate in the words of Socrates throughout the whole passage of his Apologia, and especially when associated with his first and second definitions of death. ${ }^{4}$

The difference in the significance of the two terms is also obvious in the passage $71 \mathrm{~d}$ 5-72 a 2, where the first argument for the immortality of the soul-the Cyclical or Opposites argument- is presented. We can observe in this passage that each of the two terms has a different opposite, and this is an indication that its meaning differs from that

2 Olympiodorus, $3, \$ 1,6-9$.

3 Ebert (2004: 130-131) offers a thorough analysis of the semantic difference between the two terms. However, he claims that this difference seems not to have been taken into consideration within the (first) definition of death (64 c 2-8). On the contrary, Gallop (1975: 86), who also remarks on the difference between death as an event and death as a state, is of the opinion that death is treated as having both significances in its afore-mentioned definition. We will argue later that in any case Plato needs both the significances in order to define death and he deliberately uses them, because it is precisely this difference that he wants us to be aware of.

${ }^{4}$ We note the use of the two terms, sometimes in conjunction and others separately, in the following passages: apothnēskein te kai tethnanai (64 a 6), tethnanai (64 c 5, 65 a 6, 67 e 2, 67 e 6), apothnēskein (67 e 6). We can also find the participle apothnesskōn (68 b 1) and the infinitive apothaneisthai (68 b 9). Moreover, we note twice

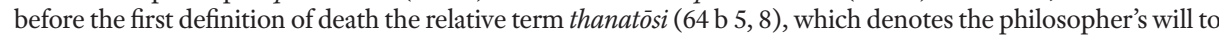
die, and also reflects the continuity of this activity which consists in dying. It is also important that this last term is supposed to be used by the multitude, so the present continuous of the verb is verified by the crowd, although they do not know the appropriate meaning and real aim of this will and activity of the philosopher. Sedley and Long (2011: 50, note 13) acknowledge that "it could also mean 'want to die"”, however, they translate the verb thanatōsi in passages 64 b 5 and 8 as 'be near death', because in passage 65 a 6, where Socrates also refers to the opinion of the multitude, it is said that philosophers come 'pretty close to being dead'. Considering the meaning of a similar expression of modern Greek language, I believe that this second translation of thanatosi could also be plausible. On the meaning of thanatōsi see also Burnet (1911: 64) and Loriaux (1981: I, 75). 
of the other term. Whereas tethnanai (death in the sense of being dead) is opposed to the infinitive zèn (life in the sense of being alive), apothnèskein (the act of dying) has another opposite, the infinitive anabiōskesthai (return to life). ${ }^{5}$ In the passage mentioned above, both apothnēskein and anabiōskesthai are considered to be generations, i.e. processes. Anabioskesthai expresses the birth of the dead into the world of the living. On the one hand tethnanai as a state is opposed to the state of $z \bar{e} n$, while on the other we have two opposite processes or generations, the act of dying and the return to life. So the difference between tethnanai, meaning a state, and apothneskein, meaning a process, is again obvious. ${ }^{6}$

Olympiodorus notes that the philosopher's willingness to die is shown in the text $\mathrm{t}^{7}$ by a hypothetical syllogism, as follows: "If the philosopher trains himself for death, it follows that when death comes, he is not afraid, is not indignant, does not cringe; the former is true; therefore so is the latter" ${ }^{8}$ He remarks that Socrates proves the major premise in a few words, saying that it is foolish, if one has spent all one's life preparing for a thing and pursuing it, namely, in this case to die and be dead, then to be afraid when it comes. Immediately after this remark, Olympiodorus states that there are no grounds for this objection. He explains that the philosopher's preparation for death and his pursuit of it, i.e. those activities which are connected with the voluntary death, do not need as an extra end the bodily or physical death, because they are already complete activities. According to Olympiodorus' exegesis “...every activity that is complete in itself has its end in this very completion and does not need an additional end (for example, when we want to

5 I follow Jowett in the translation of terms.

${ }^{6}$ Ebert (2004: 130-131) in his interpretation stresses the difference between apothnēskein and tethnanai, considered through the difference between death as an event and death as a state. He then points out that one can accept and verify the definition of death as an event and reject the definition of death as a state. So, as he correctly puts it, one can reach the conclusion that the separation of the soul from the body, which is mentioned in the definition of death (64 c 2-8), in no way implies that the soul can exist independently of the body after this separation. The state, i.e. the separated condition of soul and body, does not necessarily follow the event, nor does the event necessarily bring about the state. However, I believe that it is crucial for any reader of the dialogue to understand also the difference between apothneskein and tethnanai as a difference between a process and a state. Ebert (2004: 130-131) recognizes that the process is represented in the definition of death ( $64 \mathrm{c} 5)$ by the meaning of the word apallage, which according to him means "separating" and not "being separated". Considering passage 67 e 6 , I believe that the process is denoted by apothneskein; this infinitive signifies the constant effort of the philosopher to purify his soul, i.e. to make it separate from the body, and this is a continuous experience which amounts to a way of life. It is necessary for Plato to show that death is also a process, in order to clarify that the voluntary or philosophical death is a way of life. Ebert (2004: 126-128) claims that Plato uses the section of the Apologia in the Phaedo in order to attribute to Socrates the characteristics of a Pythagorian philosopher. He recognizes two main issues that Plato brings to the fore in this section: a) philosophy as a certain way of life, a notion with Pythagorian origin; Ebert stresses the fact that the only reference by name to Pythagoras in the whole platonic corpus is passage $600 \mathrm{~b}$ of the Republic, where Pythagoras is presented as founder of a certain

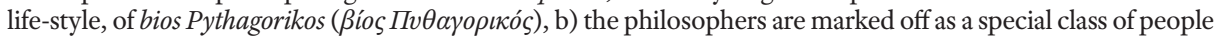
who are strictly discerned from other people. Frede (2010: 25) also believes that Plato recognized in Socrates' personality the incarnation of the ideal of Pythagorian life. Because of his ascetic life and his independence from the needs of the body, Socrates served as the most effective representative of this philosophical way of life within the philosophy of transcendence and afterlife.

\footnotetext{
7 Plato, Phd. 64 a 6-9.

${ }^{8}$ Olympiodorus, 3, $\$ 2,1-6$.
} 
pray it is for the sake of prayer itself), and if, further, the pursuit of death is an activity complete in itself, the philosopher will not need another end (death itself), but his whole existence will be a continuous pursuit of death". ${ }^{9}$

Olympiodorus' reasoning aims to prove that the pursuit of death is a totally autonomous, purposeful, and intentional activity, which has an end entirely different and independent from bodily death, i.e. the voluntary (or philosophical) death. Of course this raises the question as to what the difference is between the two ends. Olympiodorus is ready to answer this question by emphasizing the difference between dying and being dead, and in order to further clarify it he draws an analogous distinction between the man who is in search of purification (the kathartikos) and the contemplative man (the theōrētikos). He answers as follows: "Preparation for death is not an end in itself, and this example of prayer is different: the real end is being dead. For the same reason 'dying' is distinct from 'being dead'; one in search of purification, who is training himself for death, is 'dying', that is to say, purifying himself of affects, while the contemplative is already 'dead', because he is free from affects, and therefore he will not make dying his object". ${ }^{10}$ Consequently, we can assume that for Olympiodorus, although preparation for death and the pursuit of it, i.e. apothneskein (dying), is an activity complete in itself which has its end in this very completion and does not need an additional end, it is not an end in itself (haplōs telos). The real end is the state of being dead (tethnanai), and being dead is construed by Olympiodorus as "being free from affects"; which is why he attributes the achievement of the real end only to the contemplative man.

Damascius also stresses the difference between apothneeskein (to die) and tethnanai (to be dead) in his commentary on Plato's Phaedo. According to his explanation, if our aim is to detach (chōrizein) the soul from the body and to achieve complete detachment (kechōrikenai teleōs), the latter being the final goal, the former a way to the goal and a pursuit, and if achieving one's end always causes joy, it would be ridiculous to think that the philosopher alone should grieve when he attains his own goal; he adds that the major premise of this syllogism is self evident, whereas the minor is substantiated at greater length. ${ }^{11}$ Furthermore, he gives two alternative justifications for the use of the double infinitive, apothnēskein and tethnanai, in the platonic text; Plato has chosen to use these two terms either because purification is twofold: it may mean either "to become pure" (kathairesthai) or "to be pure" (kekatharthai), or because he wanted to mark off the end as distinct from the action and the action as incomplete and directed towards the end. ${ }^{12}$

Following the same line of reasoning as Olympiodorus, Damascius divides the actions into those which encorporate their ends and those which have a further goal not included

9 Olympiodorus, $3, \$ 2,6-\$ 3,1$.

10 Olympiodorus, $3, \$ 3,1-6$.

11 All references to the text of Damascius' Commentary on the Phaedo are from Westerink (2009). See Damascius, I 49, 1-5.

12 Damascius, I 51, 1-4. 
in the action. In order to clarify this distinction Damascius cites the following examples: "It is not, indeed, with every action that we aim at having completed it; e.g. in the case of intellection, we want to exercise this faculty always, not to have exercised it, because in this case there is no other goal; ${ }^{13}$ similarly with prayer, which has its own perfection, if euchesthai ('pray') means tou eu echesthai ('cling to the Good')". ${ }^{14}$ We notice that while Olympiodorus implies the existence of two kinds of end, Damascius prefers to emphasize the existence of two kinds of action. Although Olympiodorus acknowledges that apothneskein ("dying") is an action complete in itself, which means that it has its end in this very completion, he attributes the qualification "real end" or "absolute end" (haplos telos) only to tethnanai, i.e. to "being dead". On the other hand Damascius prefers to make clear the distinction between the action and its end and stresses the difference between the incomplete and the complete action. In the case of the incomplete action there is always another goal to be achieved, while the complete action has its own perfection in itself without the need for an extra end or goal. According to Damascius "being dead" or kechōrikenai teleōs or tethnanai is the philosopher's own goal (oikeion telos). ${ }^{15}$

\section{The true philosopher's attitude towards death}

It is the custom of Plato to display the extent to which the philosopher's attitude differs from that of the multitude. In the Apologia of Socrates in the Phaedo, he not only speaks of philosophers but also those who practise philosophy in the right way (64 a 4-5), of the true philosophers (63 e 9-10). Olympiodorus states that Socrates speaks of the 'true philosopher' not in contradistinction to the sophist who pretends to be a philosopher, but in contradistinction to the statesman. ${ }^{16}$ The statesman (politikos) in the Neoplatonic terminology of Olympiodorus (and Damascius) is a level of man lower than the level of man who is in search of purification (kathartikos), and two levels lower than the contemplative man (theōrētikos). The statesman is the kind of man whose soul uses his body as an organ. ${ }^{17}$ Olympiodorus explains that the statesman is not a philosopher in the strict sense, because under circumstances he will make use of the affects, too, anger and desire: anger to defend his country against its enemies, desire, because he is interested also in the body and in the temporal world. ${ }^{18}$ Since the subject of the dialogue is purification, as it is

${ }^{13}$ Cf. Aristotle, Metaphysics, 1048 b 18-28.

14 Damascius, I 51, 4-6.

15 Damascius, I 49, 4.

16 Olympiodorus $3, \$ 6,1-4$.

17 See Olympiodorus, Commentary on the First Alcibiades of Plato, 204, 12-13; 205, 4-6; 209, 24-210, 4; Westerink 1956.

18 Olympiodorus, $3, \$ 6,5-7$. 
recognized by Olympiodorus, ${ }^{19}$ we can assume that the true philosopher is the man who is purifying himself from affects, i.e. the man who is training himself for death, the man who is dying, the kathartikos, because only that kind of man can manage to be already dead some time, i.e. free from affects, a contemplative man.

Regarding the passage 64 a 4-b 9 both Olympiodorus and Damascius recognize that the divergence of views between ordinary men, i.e. the multitude, and the philosophers, is due to the fact that they consider life and death from totally different perspectives. Damascius states that while the philosopher's life is outside the body, the ordinary man's is mixed up with it; accordingly to the ordinary man 'loss of life' (azōia) means death, to the philosopher, however, it means the life determined by the body. ${ }^{20}$ In response to the remarks by Socrates in passage 64 a 4-9, Simmias replies: “By Zeus, Socrates, I don't feel much like laughing just now, but you made me laugh. For I think the multitude, if they heard what you just said about the philosophers, would say you were quite right, and our people at home would agree entirely with you that philosophers desire death, and they would add that they know very well that the philosophers deserve it" (64 a 10-b 6). ${ }^{21}$ But Socrates raises an objection concerning the matter of knowing very well: “...For they do not know in what way the real philosophers desire death, nor in what way they deserve death, nor what kind of a death it is" $\left(64\right.$ b 7-9). ${ }^{22}$

Olympiodorus notes that in this passage as a whole (64 a 4-b 9) contradictory conclusions have been reached: "Simmias says that people are aware that philosophers long for death, Socrates says they are not, and the rejoinder is that they are". ${ }^{23}$ Furthermore Olympiodorus pinpoints the cause of these contradictory conclusions; the cause is homonymy. ${ }^{24}$ Death can equally mean either "bodily", i.e. physical, death or "voluntary" death, but most people cannot understand this second meaning of the word. Consequently, according to Olympiodorus, people are not aware that philosophers train themselves for voluntary death, and this is what Socrates means by saying that they 'long for death', in other words, they detach themselves from the body. Also, when Socrates states that people do not know what kind of death the philosophers deserve, he means that they deserve the voluntary death; but on the other hand, according to Olympiodorus, they are well aware that philosophers train themselves for bodily death, which the philosopher will choose also, inasmuch as it is an image (eidōlon) of voluntary death. ${ }^{25}$

19 Olympiodorus, 3, \$6, 4-5.

20 Damascius, I 52, 1-3.

21 Transl. Fowler (Plato 1914).

22 Transl. Fowler.

${ }^{23}$ Olympiodorus, 3, \$11, 1-4. L.G.Westerink correctly remarks in his apparatus criticus that either Olympiodorus or the redactor mixed up the speakers; the correct reading would be: "Socrates says that people are not aware that philosophers long for death, Simmias says that they are aware, and the rejoinder is that they are not."

${ }^{24}$ Olympiodorus, $3, \$ 11,4$.

25 Olympiodorus, $3, \$ 11,4-8$. 
Olympiodorus' suggestion that bodily death is an image (eidōlon) of voluntary death is of tremendous importance, because it shows the superiority of voluntary death over bodily or physical death, through a terminology which evokes the platonic ontological relation between the original and its image, between the pattern and its copy, i.e. the Form and the sensibles. Images imitate their originals, so the bodily death is a death only inasmuch as it imitates the voluntary death. But why is voluntary death an original death, a real death, whereas bodily death is not? What is it that is missing from the bodily or physical death and in what way is the bodily death deficient in comparison to the voluntary one?

It seems that the bodily or physical death cannot be recognized as an original death, because original death presupposes that the soul has striven to detach itself from the body and become purified from affects during the lifetime that it was attached to the body. Only the preparation for death and constant effort of purification of the soul ensures that when bodily death occurs, there will be total and perfect separation of the soul from the body. The bodily or physical death could occur at any time by chance, without the active participation of the soul in the procedure of purification during one's life. Thus, the original death is much more a way of life which involves preparation for death and presupposes a choice for this preparation, i.e. the voluntary death, than a death which occurs by chance or a death that just occurs as an event, as is the case in bodily death. The whole issue will be clarified when we will examine the relation between purification and death.

Damascius observes that there are three things concerning voluntary or philosophical death that outsiders fail to see: 1 ) the subject of the death for which the philosopher prepares himself 2) the character of this kind of death and, finally, 3) the cause of death. The subject of the death for which the philosopher prepares himself, according to Damascius, is the soul, not the living organism; besides, its character is life pure and unalloyed, and not bodily death; finally, its cause is the pursuit of wisdom, not suicide. The cause is expressed in the words "how they long for death"; the subject by the words "in what respect they deserve death", that is, with regard with the soul; while the words "what kind of death" indicate the character of this death, that it is life without admixture

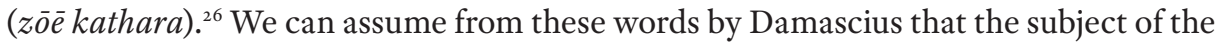
bodily death is the living organism, its character is nekrōsis or mortification and its cause anything other than philosophy.

\section{The definition of death}

In passage 64 c 2-8 Socrates gives a definition of death. Olympiodorus states that Socrates defines death as a separation not only of the soul from the body, but also of the body from the soul. The only difference is that referring to the soul he speaks of 'being' (einai),

\footnotetext{
26 Damascius, I 53, 1-5.
} 
because it is ungenerated, while in the case of the body of 'having come to be' (gegonenai), because it is generated..$^{27}$ Olympiodorus points out that Plato deliberately mentions both in the definition, the separation of the body from the soul and the soul from the body, because in the case of souls that cling to the body the body is severed from the soul, not the soul from the body, with which it is still linked emotionally by what is termed a 'half-relation' ${ }^{28} \mathrm{He}$ then reminds us that from those souls come the shadowy apparitions that hover about graves, as it is said in the Phaedo ( $81 \mathrm{~d} \mathrm{1})$, and as Homer says (Il. XVI 857) about the soul of Patroclus. ${ }^{29}$ Olympiodorus also clarifies that death is separation not for all soul without exception, but only for rational soul, because irrational soul is extinguished with the body; he then adds that we speak of separation not solely with regard to things that can be separated, but also things that exist separately. ${ }^{30}$

Damascius refers to the advantages of this definition of death and highlights that it has all the points a definition should have; it is evident, brief, exact, and scientific. ${ }^{31}$ The definition is evident, for if life is admittedly a union of soul and body, death must be the reverse. In addition to this, it is brief because it is expressed in the necessary minimum of words. According to Damascius the definition is exact for three reasons: 1 ) it deals with death as a state, not as a process 2) the death it describes is total death, which detaches the soul from the body as well as the body from the soul 3) the third reason is linked with Olympiodorus' remark previously referred to: with regard to the soul it speaks of 'being' (einai), with regard to the body of 'having become' (gegonenai). Finally, according to Damascius, the definition is scientific because, death being twofold, it covers the whole kind, which comprises both the aspects.

27 Olympiodorus, $3, \$ 13,1-5$.

28 Cf. Proclus, Commentary on Plato's Timaeus, Book III, 142, 23-27: "And if you want to adopt the terminology of the noble Theodore on these matters, then the intellect stands in no relation (aschetos), while the life that pertains to bodies does stand in a relation, and the soul is intermediate between these, being a certain sort of quasi-relation (hêmischetos tis)" (transl. Baltzly 2009).

29 Olympiodorus, $3, \$ 3,13-\$ 4,6$. Gallop (1975: 86) points out that the definition of death leaves it unclear what is the proper subject of the predicate "dead": "Is it only the man who is to be called 'dead' when soul and body are parted, or may 'dead' be predicated of soul and body separately?”. Gallop reminds us that Socrates will generally avoid speaking of 'dead souls', because the conclusion of the dialogue is that the soul is 'deathless'. We have already seen (n. 26 above) that Damascius supports that the subject of death for which the philosopher prepares himself is the soul, not the living organism. This might mean that of major importance is death as a separation of the soul from the body, and that the vice-versa is mentioned in the definition only for the sake of the complete separation of the soul from the body, i.e. to denote the need for this complete separation, as Olympiodorus suggests in his exegesis. We might also construe soul as the subject which survives the transition from life to death and vice-versa, a subject which is presupposed in the first argument on the immortality of the soul; see Bormann (2003: 97-99).

${ }^{30}$ Olympiodorus, 3, $\$ 4,7-10$.Cf. Bostock's remark (1986: 25-27): "What the philosopher is concerned with is called 'reasoning' ( 65 c 2) and described as reaching out for the forms 'by pure intellect alone' (66 a 2). Pursuing this goal, the philosopher is already separating his soul from his body as much as he can, and in that way practising for the complete separation that death will bring. We must presumably infer that pure reasoning will continue into the separated state, but nothing else will...Although there is no direct statement in the Phaedo that it is only the faculty of pure reason that survives into the disembodied state, that must surely be the implication of Socrates' Defence".

${ }^{31}$ Damascius, I 59, 1-8. 
It is odd that Damascius characterizes the definition as exact because it deals with death as a state and not as a process, since death as a process is a crucial issue in this part of the dialogue, in the Apologia of Socrates. One would expect that the definition would be such as to also encompass this kind of death. Here, in the Apologia of Socrates in the Phaedo, death is twofold in a principal sense, since the main point is that Socrates presents the voluntary or philosophical death in contradistinction to the bodily death. However, according to Damascius there are also two other kinds of twofoldness of death. The first point of view from which death is considered twofold is illustrated in the definition of death; death is a separation of the soul from the body, but also of the body from the soul. But death is twofold also under another point of view according to Damascius: on the one hand it is a striving upwards to the superior, on the other a tending downwards to the inferior. Damascius stresses that in connection with human souls Plato mentions both, in the Gorgias (493 a 1-3) the death that brings us down to the body as a tomb, and in the present passage of the Phaedo (64 a-65 a) the death that is a deliverance and a resurrection from the body. ${ }^{32}$

Damascius also states that death as defined here is not the death of a form of life attached to a substrate, since it cannot free itself from the body and lead a separate existence; nor does it apply to ever perfect souls, those of Gods and genii, whose bodies cannot exist by themselves separated from their souls; it belongs to the intermediate form, in which each can exist without the other. ${ }^{33}$ Damascius' remark means that the definition of death given by Socrates in passage 64 c 2-8 concerns only this kind of coexistence of soul and body which consists in a dissoluble union; this union is an intermediate form in comparison with the other two forms of union, where each cannot exist without the other.

\section{The philosopher's practice of dying}

Ammonius in his In Porphyrii Isagogen sive V voces, in order to clarify the meaning of the definition of philosophy as the "practice of death" (melete thanatou [81 a], transl. H.N. Fowler), explains the way in which the "practice of death" must be understood. The need for this explanation is fully and clearly demonstrated by Ammonius through the citation of the story of Cleombrotus, a story which appears in a number of sources and is first depicted in a poem of Callimachus. ${ }^{34}$ According to Callimachus' epigram, Cleombrotus after having read Plato's Phaedo threw himself from a wall to his death. Cicero also includes this story in the first book of his Tusculanarum Disputationum ad Brutum: "Callimachi quidem epigramma in Ambraciotam Cleombrotum est, quem ait, cum ei

\footnotetext{
32 Damascius, I 61, 1-4.

33 Damascius, I 60, 1-5.

${ }^{34}$ Callim. 53 Gow and Page. See also Warren (2001: 93-94).
} 
nihil accidisset adversi, e muro se in mare abjecisse lecto Platonis libro" (Tusc. Disp. I 84). ${ }^{35}$ This story of Cleombrotus, as it is told by Callimachus in his epigram, is cited by Ammonius in order to show how someone might misunderstand the definition of philosophy as "practice of death", and more specifically the meaning of "practice of death" (meletē thanatou). ${ }^{36}$

According to Ammonius'exegesis, given that man is composed of soul and body, both the link between soul and body and the release of soul from body are twofold; on the one hand there is the so called physical bond between soul and body, according to which the body is bound up with the soul and the soul gives life to the body; on the other hand there is the voluntary bond between soul and body, according to which the soul is bound up with the body and is a servant of the body, being dominated by it. Consequently, the release is also twofold: on the one hand release of the body from the soul, on the other hand release of the soul from the body. Death is also twofold: on the one hand there is the physical death, a kind of death which all men experience and which consists in the separation of the body from the soul; on the other hand there is the voluntary death according to which philosophers practise dying, cultivating the separation of the soul from the body. This is what we must understand when we hear that philosophers practise dying, i.e. parting of the soul from the body. ${ }^{37}$

Ammonius also points out that the separation of body from soul does not necessarily entail the separation of soul from body; souls that cling to the body (philosomatoi) still care for it after death, and from them come the shadowy apparitions that hover about graves..$^{38}$ This remark of Ammonius reminds us of a very similar one by Olympiodorus which we have already referred to. Olympiodorus suggests that souls that cling to the body are still linked emotionally with it after death and that they remain trapped in a "half-relation" with it. This is why according to his exegesis, Plato mentions in his definition of death not only the separation of the body from the soul, but also of the soul from the body. ${ }^{39}$ Furthermore, Ammonius puts forward another relevant statement which we could consider as a complementary explanation of this double separation, mentioned in the definition of death. He points out that the body is not entirely separated from the soul even when the soul is separated from the body; the evidence for this are those who live a philosophical way of life, who while still alive are separating themselves from the body. ${ }^{40}$

In passage 64 e 8-65 a 2, Socrates asks Simmias if it is clear that the philosopher, more than other men, separates the soul from communion with the body (transl. H.N. Fowler).

\footnotetext{
35 "There is a certain epigram by Callimachus about Cleombrotus of Ambracia, who he says having read Plato's book threw himself from a wall into the sea although nothing bad had happened to him”.

36 Ammonius, 4, 15-27. All translations of Ammonius are my own.

37 Ammonius, 5, 8-19.

38 Ammonius, 5, 19-23.

39 See above n. 27, 28, 29.

40 Ammonius, 5, 23-27.
} 
Damascius asserts that Plato, too, makes separate activity the proof of separate existence, before Aristotle had used this argument. ${ }^{41}$ So following Damascius, we can assume that the purport of the Socratic conclusion, "it is evident that the philosopher detaches his soul from the body", which is expressed in the above passage, is to show two things; the first, that the natural aim of the soul is to have a separate activity since it has a separate existence; the second, that only the philosopher can understand that the soul deserves its detachment from the body, because this is a necessary presupposition of its separate and autonomous existence. Indeed, this presupposition is not only ontological, but also logical, because it can be construed as a proof of the soul's separate existence.

Olympiodorus suggests that Socrates proves the philosopher's willingness to die from his way of life first, and then establishes this same thesis from the point of view of knowledge. ${ }^{42}$ The commentator states that in the domain of life there are three kinds of activities: 1) those natural and necessary, such as feeding and sleeping 2) those natural but not necessary, such as copulation 3) those neither natural nor necessary, as the concern for elegance and colorful clothing etc. So, given that there are these three kinds of activities, the philosopher, according to Olympiodorus, will do entirely without those that are natural but not necessary and those that are neither natural nor necessary, he will even resist them forcibly, while with the first kind he will deal briefly and perfunctorily, not to the point of repletion..$^{43}$ The philosopher, apart from the absolutely necessary, disdains

${ }^{41}$ Damascius, I 72, 1-3.

${ }^{42}$ Olympiodorus, $4, \$ 1,2-4$. However, the philosopher's choice to follow a certain path in order to reach and acquire true knowledge presupposes a way of life. This is obvious in the comments of Damascius and Olympiodorus relating to the passage $66 \mathrm{~b} 4$. Damascius $(\mathrm{I} 101,5-6)$ states with reference to $66 \mathrm{~b} 4$ that the reasoning is called a 'trail' (atrapos), because the philosopher, following the Pythagorean maxim, does not 'tread the highways'. Olympiodorus $(5, \$ 4,5-11)$ also suggests that when Socrates says "we should follow this trail" means "we should not follow the highway" and furthermore "we should lead the life of purification", for the highway that we must avoid is the way of the masses and the 'trail' (atrapos) is the road of purification, which leads to contemplation. He also adds that these words of Socrates are linked with the Pythagorean precept to shun the highways, as it is testified in Callim. frg. 1, 25-26. Archer-Hind (1894: 19-20) claims that Olympiodorus' explanation has largely contributed to the perplexity of this passage. He believes that atrapos means rather a short cut, and that this short cut, in comparison with the long and tedious effort of the philosopher during life, is death. I believe atrapos, here, rather means a way out of the difficulties or the troubles that the body causes the soul, than "a short cut to the goal of our life's endeavour", as Archer-Hind suggested.

43 Olympiodorus, 3, $\$ 5,3-12$. Gertz (2011: 29) presents two readings of the voluntary death. According to the first, the 'ascetic' reading, the voluntary death concerns the abstention from bodily pleasures. According to the second, the 'evaluative' reading, the philosopher's death could be concerned more with the right attitude towards pleasures and the concerns of the body, as something of little value requiring a degree of internal detachment. Gertz claims that, in principle, this latter kind of detachment need not entail avoidance of all or even most physical pleasures, although it may be compatible with it. I believe he is correct when he associates the ascetic with the evaluative reading, since normally the value system which one believes determines the way of life chosen. I agree with Gertz that for Olympiodorus and Damascius, the notion of "voluntary death" would involve both an evaluative stance and elements of an ascetic life. I believe the evaluative stance is a prerequisite for the philosopher's choice to practise dying. However, I also consider that this evaluative stance of the philosopher definitely envolves only little time caring for the bare necessities of life, i.e. for natural and necessary pleasures (food, drink and sleeping), and avoidance of all of the rest of bodily pleasures. This is what purification and practice of dying demands. My view is that, generally, theory and praxis are not two different levels for the philosopher in Socrates' Defence in the Phaedo, so the evaluative stance is interwoven with the philosopher's ascetic way of life. 
and ignores the body. Furthermore, in the domain of knowledge one can see that the philosopher despises the senses; so, he despises also the body in which the senses reside. ${ }^{44}$

According to the Neoplatonic approach that Olympiodorus presents in his commentary, the soul has three kinds of activity: either it turns towards the lower, when it apprehends things sensible; or towards itself, when through itself it sees all that exists, for soul is a 'sacred image uniting all forms', that is, possessing the principles of all things that are; or again it lifts itself up to the intelligible by contemplating the ideas. ${ }^{45}$ What is extremely interesting in Olympiodorus' presentation is that he does not claim that the division into the three Neoplatonic types of man, the statesman, the man whose concern is purification and the contemplative man, corresponds to the three kinds of soul's activity. On the contrary, each of them must know all three activities. The statesman does not know only things sensible in civic life, but organizes the visible world according to the principles (logous) which reside in his soul, having his eye directed upon the soul. But his eye is oriented each time towards a different part of the soul which is connected with the specific social class he is concerned with; when he wants to guide the leaders his eye is directed upon reason, when he wants to guide the soldiers it is upon the spirit, and when the laborers upon desire. He also shows the leaders, by their education, the way upwards to the Good, so he must have knowledge of all three. ${ }^{46}$

Also, the man whose concern is purification knows all the three activities, because from the intermediate where his activity is placed he can acquire knowledge of the extremes. Finally, the contemplative man knows sensible things as far as he reduces them from their own plurality to the unity of the intelligible; furthermore, he reduces the unity in the intelligible to the unity that is in God, for God is nothing but unity proper without multiplicity, i.e. a monad without multiplicity. ${ }^{47}$ Olympiodorus points out that the differ-

\footnotetext{
${ }^{44}$ Olympiodorus, 4, $\$ 1,4-6$. We note that Olympiodorus recognizes two aspects of the philosopher's practice of dying; the one concerns implementation of this practice in the domain of the way of life, the other in the domain of knowledge. However, it is worthwhile considering if behind these two different aspects is the same factor which activates the twofold realization of this practice, namely detachment from senses. According to Chen (1992: 54, 14, 15), in the section on the philosopher's pursuit of the knowledge he longs for, two methods are mentioned; the first one is the basic method for acquiring knowledge of the Ideas: know the object in its purity by the subject purified, i.e. through the soul's direct contact with reality, specified as the intellectual seeing or vision of the Ideas; this method is not available to the philosopher until afterlife. The other is the method of the practice of dying which consists in the purification of the philosopher's soul from bodily infections by detaching it from senses or sense organs. What is possible in the present life is the philosopher's practice of dying (1992: 17). But what is most important is that Chen unifies, somehow, within the frame of this method of the practice of dying, the way of life and domain of knowledge, since he declares that even the refuge-taking in $\log 0 i(99 \mathrm{~d}-100$ a) is related to the detachment from senses which is presented in the earlier section $(63 \mathrm{e}-68 \mathrm{c})$. Chen, referring to passage 99 e 4-6, states that "The escape here spoken of is the detachment from senses...in escaping the soul turns away from sensible objects to logoi. This is its refraining from using senses, or the detachment from them. Practice of dying is such a detachment" (1992: 30). Therefore, according to Chen (1992: 30, 54), the escape here in question and the method of hypothesis in this later section of the Phaedo does indeed exemplify the practice of dying of the earlier section.
}

45 Olympiodorus, $4, \$ 2,1-4$.

46 Olympiodorus, 4, \$3, 1-5.

${ }^{47}$ Olympiodorus, 4, $\$ 3,6-11$. 
ence between those committed to civic life, to purification, or to contemplation, does not lie in the different kinds of soul's activity they have, but in their different attitude towards the body as well as in the way they draw their conclusions. The statesman is concerned also with pleasure and pain, for he uses the body as an instrument and his aim is not freedom from affects, but moderation in them, whereas those committed to purification or to contemplation pay attention to the body as a talkative neighbor in order to prevent it from being a hindrance to their activities, and their aim is freedom from affects. ${ }^{48}$

In addition to the above mentioned, there is another difference between the statesman and the others: ${ }^{49}$ the statesman depends on one particular premise for his conclusions, because he uses the body as an instrument and is therefore concerned with actions; actions are particular and the particular is individual. On the contrary, those engaged in purification or in contemplation are concerned with universal forms. But still there is a difference between them, because the man in the stage of purification is concerned with the differentiated forms which exist within the soul, whereas the man in the stage of contemplation is concerned with the undifferentiated forms which exist in the intel-

48 Olympiodorus, 4, $\$ 3,11-16$. Brickhouse and Smith assert that "the Phaedo seems clearly to present a somewhat different view of the appetites and the passions than what we find in the earlier dialogues" (2010: 198). The most striking characterization of the appetites and passions in the Phaedo, according to them, is that Plato has Socrates characterize all such desires as entirely somatic rather than psychological (2010: 196). In their view (2010: 197), if we compare this attitude "with Socrates' claim in the earlier dialogues that a prudent man should maintain his appetites and passions in a disciplined condition in order to avoid coming to the afterlife with a damaged (or worse, ruined) soul (see Gorgias 526 b 6-e 1)" we can understand that "the view here, in the Phaedo, seems far more extreme." In the accounts of the afterlife Socrates gives in the earlier dialogues "the afterlife does not promise freedom from at least some appetites and passions, and so it does not seem to be a feature of the Socratic view that all appetites and passions are simply bodily, nor would one reasonably look forward to being entirely free of appetitive or passionate desires as a result of the parting of soul and body at death...The experience of psychological conflict in deliberation is never in the earlier dialogues characterized so sharply as strife between the soul and the body" (2010: 197). However, Brickhouse and Smith admit that the contrast they have drawn here is, in fact, not consistently maintained in the Phaedo. Not only, as they state, "in other passages in that dialogue we hear a great deal about appetites and passions a soul can carry with it into the afterlife, particularly in cases other than the true philosopher" (2010: 198), but even in case of the true philosopher purification consists in "the parting of the soul from the body as far as possible ...both in the present and in the hereafter..." (67 c 5-d 2; transl. Gallop 1975). Rather the emphasis that Plato lays on the association of the affects with the body must be construed, as Bostock correctly suggests, from the point of view of the soul's embodiment: “...Plato is not saying, as a first reading might suggest, that while it is the soul that engages in reasoning it is the body that perceives, desires, fears, and so on. If that were his view, it would be difficult to explain how the body's doing these things could so upset the soul, or why getting rid of these desires \& emotions should count as purifying the soul...Rather, it is the soul that actually does these things, but it does them when it is in a body, and because of the body it is in" (1986: 26). Hackforth (1955: 49 and note 1) points out that the aim ascribed to the true philosopher in this section of the dialogue - the greatest possible detachment of soul from body - is a Platonic rather than a Socratic doctrine, because, outside the Phaedo, Socrates' general attitude does not seem to be that of an enemy of the 'flesh' and its pleasures, but of a "master of himself", one who is not to be overcome by pleasure. In my view, it seems that the Neoplatonic level of statesman whose aim is not freedom from affects, but moderation in them, corresponds to the Socratic view of the early dialogues where maintenance of appetites and passions in a disciplined condition and moderation in affects is the central request. Furthermore, in the Phaedo, which according to Olympiodorus is a kathartikos dialogue (see n. 18, 19), i.e. a dialogue whose subject is purification, Plato's attention has been focused to the kathartikos man, as it is said in the Neoplatonic terminology, i.e. to this man whose concern is purification, because this is the only true philosopher, since he conducts his life devoted to eventual purification both in the present and in the hereafter.

49 Olympiodorus, 4, $\$ 4,1-14$. 
ligible world; on the intelligible plane all the forms are united inseparably, because they interpenetrate.

\section{Purification and death}

In passage $67 \mathrm{c} 5$ - $\mathrm{d} 6$, according to Olympiodorus, ${ }^{50}$ Socrates defines death as purification of the soul from the body. In fact, what we read in this passage is that Socrates defines purification as "the parting of the soul from the body as far as possible, and the habituating of it to assemble and gather itself together, away from every part of the body, alone by itself, and to live, so far as it can, both in the present and in the hereafter, released from the body, as from fetters" (transl. D. Gallop). Then Socrates proceeds with the definition of death as "a release and parting of soul from body" (transl. D. Gallop).

However, Olympiodorus seems to identify or rather to unify the definition of purification with that of death, and he finally presents a concise formula, in which death is identified with the purification of the soul from the body. Furthermore, the commentator wonders why, having defined death before (64 c 4-8), Socrates does so again now. He then recognizes that the occurrence of two definitions of death is another instance of passing from the more general to the more particular. Olympiodorus remarks that above Socrates defined death as a separation of the soul from the body and of the body from the soul and he reminds us that he previously observed $(3, \$ 4)$ that Socrates had a good reason for mentioning both; ${ }^{11}$ however, he adds, here Socrates defines death as only a purification of the soul from the body. According to the commentator now death is more general than purification, because one who is purified necessarily dies also, whereas one who dies is not necessarily purified, witness those body-loving souls that hover about their graves even after death. ${ }^{52}$

In my opinion the idea that there are two senses of death, a broad sense and a strict sense, has already been shown and verified by the first definition of death in passage 64 c 2-8. In this first definition, the description of death (thanatos) is different to that of tethnanai, while the second seems to be a necessary clarification which puts a condition for the realization of real and definitive death. This first definition includes a first sentence where death (thanatos) is defined only as "the release (apallagē) of the soul from the body" (64 c 4-5). But it seems that this first sentence has not been deemed sufficient to denote the strict and proper sense of death, thus Socrates added the definition of tethnanai (being dead) in passage 64 c 5-8, in which he emphasizes the need for a reciprocal release of the body from the soul as well as of the soul from the body. The passage also stresses the conjunction of the terms "apart" or "separated from" (chöris) and "alone by

\footnotetext{
50 Olympiodorus, $7, \$ 2,7$.

51 See above n. 27, 28, 29.

52 Olympiodorus, 7, $\$ 2,8-15$. Cf. Olympiodorus, 3, $\$ 4,3-6$.
} 
itself" (auto kath' auto, autēn kath' autēn), which are both indispensable to the strict definition of death. Olympiodorus ${ }^{53}$ explained why this expanded formula of death, which precisely coincides with the definition of tethnanai, renders more effectively its proper and strict sense. The need for a second definition of death in order for the strict sense of death to be rendered, emerges again after the definition of purification. This second definition of death ( $67 \mathrm{~d} 4-5)$ highlights not only the release (lusis) but also the parting (chōrismos) of the soul from the body.

Bearing in mind also the observations of Olympiodorus, we can diagnose in the words of Socrates from passage 64 a to 68 a the following distinct meanings and their corresponding terms: 1) the physical or bodily death, 2) the voluntary or philosophical death, 3) apothnesskein ${ }^{54}$ as a process, as a continuous experience of dying, 4) tethnanai as the state of being dead, and its definition in passage $64 \mathrm{c} 5-8,5)$ the first definition of death in passage $64 \mathrm{c} 2-5,6$ ) purification and its definition in passage $67 \mathrm{c} 5-\mathrm{d} 2,7$ ) the second definition of death in passage $67 \mathrm{~d} \mathrm{4-5}$ (cf. $\mathrm{d} 9-10$ ).

Given that tethnanai is the state of being dead, by comparative examination of passages 64 a 5-6 and 67 e 5-7 one can reach the conclusion that apothneskein is the voluntary or philosophical death, i.e. the philosopher's practice of dying during his life-time. Furthermore, the definition of tethnanai (which is an expanded and ameliorated form of the first definition of death), along with the second definition of death, prove that in addition to “alone by itself" (auto kath' auto, autèn kath' autèn), must be added the "apart" or "separated from" (chōris); to the "release" (lusis), must be added the "parting" or the "separation" (chörismos) of the soul from the body. Only with these additions and under these conditions is death a real death. ${ }^{55}$ Neither "alone by itself" nor just "release" are sufficient conditions for the realization of death. So, we can plausibly reach the conclusion that

53 See again n. 29.

54 See again $\mathrm{n} .3$ and 4.

55 Rowe (1993: 136) remarks that in passage 64 c 5-8 there is an elaboration of the definition of death given in c 4-5 and he points out that by the 'defence' as a whole, "death" in this context means primarily the state rather than the event. He then suggests (1993: 144-145) that in passage $67 \mathrm{~d} 4-5$ there is an important modification of the original definition of death. I believe that the definition of tethnanai, which complements and integrates the first definition of death(which extends from 64 c 3 up to c 8), substantially coincides with the second definition of death(67 d 4-5) with regard to the meaning of their content. I cannot see a modification, since we have concluded that the separation of the body from the soul has been included in the definition of tethnanai only for the sake of the complete and real separation of the soul from the body; see again n. 27, 28, 29. Hackforth (1955: 53, n. 1) also remarks that "what at $64 \mathrm{c}$ was called an $\dot{\alpha} \pi \alpha \lambda \lambda \alpha \gamma \dot{\eta}$, a parting of soul from body, has now become a $\lambda \dot{v} \sigma \iota \varsigma$

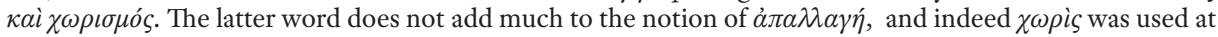
64 c 6 ; the operative word is $\lambda v \sigma \iota \varsigma$, releasing, which sums up in itself much of what has intervened". Furthermore, I discern a form of inconsistency in Rowe's interpretation of apothnēskein and tethnanai (1993: 145). He claims that "apothnēskein meletōsin"(67 e 6, 'practise dying') means "the event, which is a process of freeing"; I think it cannot be the event in this context, nor both the event and the process, but only the process. He also claims, referring to 62 a 5, that tethnanai in 67 e 6 is ambiguous between event and state. I believe that the emphasis in the section of Socrates' Defence is on tethnanai as a state, as Rowe himself recognized before. 
real death, i.e. release and parting or separation of the soul from the body, presupposes tethnanai.

On the other hand, tethnanai presupposes purification, i.e. the constant and continuous effort involved in the parting or separation of the soul from the body. This begs the question, what is the relation between purification (katharsis) and apothnesskein, and furthermore between apothneskein and tethnanai? Is there a difference between the first two or could we say that if apothnēskein is construed as a constant experience of dying, i.e. the constant experience of separating the soul from the body and habituating it to gather itself together, then apothnesskein is equated or identified with purification? In this case we could also assert that apothnēskein is a presupposition of tethnanai.

\section{Purification, separation, death}

At this point it is worthwhile to examine certain of the distinctions that Damascius prompts us to make. These distinctions may shed light on the thorny questions we have to face and answer. First of all Damascius distinguishes between pure (katharon) and true (alethes). He states that pure and true are not identical, because "pure" means that a thing is separate from everything else, and "true" that it is exactly what it is, and this is apparently the reason why it is necessary to become pure first, before we can attain truth..$^{56}$ Therefore, we shall not know the truth in our life-time, since we are not yet pure, because we have not yet died.

Furthermore, Damascius clarifies that separation (chörismos) is not the same thing as purification (katharsis). This distinction is better understood in the case of the body's separation from the soul. According to Damascius, the body, indeed, is not purified when separated from the soul, but rather it becomes unclean and therefore causes uncleanness. ${ }^{57}$ Damascius' remark shows that separation is more general than purification, because everything which is purified is also separated, whereas everything which is separated is not necessarily purified. Moreover, Damascius recognizes that his previous statement $(\mathrm{I} 124,1-2)$ about the relation between pure and separate needs a correction; he now states that in current usage a thing does not become cleaner when it is separated from the superior. In order to reinforce this suggestion he invokes passage $227 \mathrm{~d} \mathrm{6-7}$ of the Sophist, where it is clearly expressed that "purification is, of course, keeping the rest, while discarding anything that might be inferior". ${ }^{58}$

Finally, Damascius makes a clear-cut distinction between death (thanatos) and purification (katharsis). He says that only the death that detaches from the inferior is identi-

\footnotetext{
56 Damascius, I 124, 1-5.

57 Damascius, I 126, 1-2.

58 Damascius, I 126, 3-6.
} 
cal with purification..$^{59} \mathrm{He}$ then justifies this statement by saying that death is a process of separation, as it was said in the definition given in passage $64 \mathrm{c} 7-8$, and he adds that this is why we speak of death from above and death from below. ${ }^{60}$ Damascius' remark implies that since death is a process of separation, the duality of separation determines the twofoldness of death. But does this mean we can identify separation with death? Damascius hastens to raise this question regarding the relation between the state of choris einai (being separate) and the state of tethnanai (being dead): "is being separate identical, then, with being dead?" His answer is that being separate is not identical with being dead, because being dead follows a period of union, which is then dissolved by death. ${ }^{61}$ However, he recognizes that if one takes into consideration the case in which there is permanent separation, and therefore permanent dissolution and permanent death, one could pose the question: "then what difference is there between death and otherness (heterotess)?" Damascius' answer to this question is that death severs mutual relations, and so those other things must exist already.$^{62} \mathrm{He}$ then explains how death must be understood with reference to life: both inclination towards a thing and withdrawal from it are vital processes, and all relations of this kind are severed by death. ${ }^{63}$

We can see that there is complete agreement between Olympiodorus and Damascius with regard to the distinction between death and purification. In addition, Damascius specifies certain criteria which distinguish separation from purification, being separate from being dead, and death from otherness. Damascius seems to identify death with the cause of separation, since he reformulates the definition of death in passage $64 \mathrm{c}$ $7-8$, saying that "death is a process of separation". In fact, the Greek term choristikos (Damascius, I 127, 2) means that death has the capacity or is suitable to separate, so it is the efficient cause of separation. Separation is identical with purification only when it is identified with death that detaches from the inferior. Being separate (chöris einai) differs from being dead (tethnanai) in so far as the latter presupposes a prior union. On the other hand, chöris einai (being separate) coincides with tethnanai (being dead) when dissolution follows a period of union; this union is dissolved by death, but the things

59 Damascius, I 127, 1-2.

60 Damascius, I 127, 2-3.

61 Damascius, I 127, 3-4.

${ }^{62}$ From Damascius' suggestion we can conclude that death is the dissolution of a union of things that already exist (and co-exist in a union), since death's nature is to sever mutual relations. The case of permanent separation (aei chöris), the "death of everlasting beings" (see Westerink, note on Damascius \$127, 2009: 79), raises the question about the relation between death and otherness. Considering what Damascius says we can also assume that death presupposes the existence of the other, whereas otherness (heterotēs) regards things that must not already exist; other could also be two things of which one may not yet exist. That could be the case of otherness between two radically different natures, as soul and body are; soul is that which has permanent existence and body that which is subjected to generation and corruption. From this point of view, we could argue that death is the factor which helps the hidden otherness between soul and body to emerge, the factor which reveals this otherness. Soul and body are other by nature, but coexist within the psychosomatic unity of the human being and only death brings again to the fore their primary and fundamental otherness.

63 Damascius, I 127, 5-8. 
which are dissolved must already exist. This is why Socrates in his second definition of death (67 d 4-5; cf. d 9), speaks not only of separation but also of dissolution of the union of soul and body.

Drawing to a conclusion, we can assume that real separation presupposes purification, i.e. death that detaches from the inferior. ${ }^{64} \mathrm{We}$ are at the point of providing an answer to the question whether apothneskein is equated with purification, and if so whether it is a necessary condition for tethnanai. I believe that passages $67 \mathrm{~d} 8-10$ and 67 e 5-6 are parallel; the philosopher's occupation (transl. D. Gallop) and practice (transl. D. Sedley, A. Long) is just that, the dissolution of the body-soul union and the separation of the soul. In the second passage it is perfectly clear that those who truly love wisdom are in reality practising dying (transl. D. Sedley, A. Long). The words meletèma (67 d 8) and meletōsin (67 e 6) constitute the middle term which leads to the conclusion that apothneskein is equated with (or naturally bound up with or at least oriented to) lusis and chōrismos of the soul. So apothnēskein, the practice of dying, is the only real dissolution and separation of the soul which leads to tethnanai, i.e. to the state of being really dead.

Purification is defined through an infinitive which denotes and reflects the continuance and the intensity of the activity: to chorizein hoti malista (67 c 5-6: the parting of the soul from the body as far as possible [transl. D. Gallop]). Apothnèskein is also an infinitive which can be used to denote the constant effort of dying, i.e. of separating the soul from the body. Apothneskein is parting or separating the soul from the body, and this process leads to the only real lusis (dissolution or release) and chōrismos (separation) of the soul. Chen correctly points out that the soul may function either with the body, or without using sense-organs or the senses but instead relying upon thought alone so far as this is possible, or in complete separation from the body; the soul by itself is the soul purified from the body, while the soul in the second case is the soul in the process of continually purifying itself. ${ }^{65}$ So, we could equally recognize two meanings of purification which correspond to the two meanings of death; on the one hand purification as a final event and a result which brings about the state of being purified, and on the other, purification as a process. ${ }^{66}$ This process of the soul's continually purifying itself is apothnēskein.

${ }^{64}$ White (2006: 452) appears to interpret passage $67 \mathrm{c} 5-\mathrm{d} 5$ as if purification (katharsis) must be considered identical with what is called 'death'. On the contrary, Frede seems to construe death as the cause of complete purification, so she gives priority to death over purification. Frede asserts that death is what first brings about complete purification (2010: 21) and complete separation of soul from body (2010:24), without clarifying which kind of death she means, although it is probable that she means death as an event. Chen (1992: 13; cf. 16, n. 18), before Frede, follows the same line of interpretation and makes the same mistake, when with reference to passage 67 c $5-\mathrm{d} 2$ claims that "...the apallagē in question is not a complete separation since it is qualified by the phrase 'as far as possible' or some such. Complete separation is the separation of the soul from the body upon the death of the human being who is a composite of the two. At that moment the soul comes to be by itself...”. However, we have shown the error in believing that death as an event ensures the complete separation of the soul from the body, i.e. real death.

${ }^{65}$ Chen (1992: 13-14).

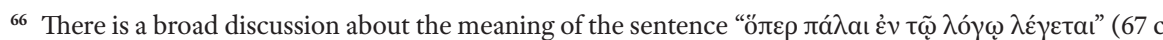
$5-6)$, which is included in the definition of purification. The crucial point is if in these words there is an allusion 
Following this line of reasoning we can now understand very well Olympiodorus' suggestion that bodily or physical death is only an image of the voluntary death, i.e. of the philosopher's practice of dying, of apothneskein, since nothing in the bodily death guarantees real separation and release of the soul from the body. The bodily death could come by chance at any time without the will and preparation of the subject who dies. But the real chōrismos of the soul presupposes the subject's will to die and the practice of dying. And this will and practice characterize only the true philosopher, since the true and correct practice of philosophy is a preparation for death, i.e.dying, apothneskein.

The distinction between the two kinds of death made by Ammonius, Olympiodorus and Damascius is of crucial importance. This distinction between bodily or physical death and voluntary (chosen or intentional) death, which the ancient commentators emphasize and explain following Plato, shows that the unphilosophical suicide, although also a kind of voluntary death, must not be confused with the voluntary philosophical death. The first offers just physical or bodily death and does not guarantee real separation and release of the soul from the body, since it is irrelevant to the preparation for death, and for this reason (but not only for this reason) is an irrational choice within the platonic frame ${ }^{67}$ Conversely, voluntary death consists in the practice of dying and the preparation for death, and is exactly the process which ensures the real death, i.e. the lusis and chörismos (release or dissolution and separation) of the soul from the body, which is

to the religious dimension of the purification which is linked with Orphic-Pythagorean doctrines (see Loriaux 1981: I, 93-95). It is indisputable that at the end of his Defence, Socrates associates philosophical purification with religious purification (69 c-d). Bostock (1986: 29) points out that the Phaedo contains two distinct views of life after death: one, which is very much a philosopher's view, and is applied to the philosopher's death, supposes that at death the disembodied soul will be capable of pure reasoning but nothing else; the other, which is the more usual religious view, and is applied to other deaths, supposes that pretty well all the conscious activities of ordinary living human beings will persist into the disembodied state. The two views are reconciled, according to Bostock, by a religious doctrine which Plato took over from Orphics and Pythagoreans. This doctrine focuses on the religious motifs of sin, purgatory, reincarnation, and eventual purification and release from the "wheel of rebirth". I consider that the religious doctrine of eventual purification is the pillar of the notion of philosophical death in the Phaedo. It is crucial for anyone to understand the strong connection between this religious doctrine and the philosopher's view of death, as well as the philosopher's practice of dying which consists in a way of life. The philosopher's view of death cannot exist apart from this religious doctrine of eventual purification, because it is grounded in it, since purification itself has been defined (67 c 5-d 2) as a process which takes place "both in the present and in the hereafter" (transl. Gallop 1975).

${ }^{67}$ Warren (2001: 101) seems to misunderstand the distinction between the voluntary or philosophical death and the unphilosophical suicide. He claims that of itself the introduction of the notion of volition, on which Ammonius and Olympiodorus focus their distinction between the two kinds of death, the natural and the chosen or intentional (or voluntary) death, does not help a great deal, since the required distinction is not between death per se and the philosophical practice of death, but between the voluntary death of suicide (as for example, achieved by Cleombrotus) and the voluntary philosophical desire to separate soul and body. To this objection we must answer that the volition introduced by Ammonius and Olympiodorus is not random, but only the philosopher's volition. We have demonstrated that the voluntary philosophical death is a presupposition of the real death, i.e. of the release and parting of the soul from the body, so the original and proper distinction of two kinds of death includes only the natural death and the voluntary philosophical death, which leads to the real death. If we follow the argumentation of Warren, then we could have three kinds of death: the natural death, the voluntary philosophical death, and the voluntary unphilosophical suicide. But this division is not proper, in my opinion, because the voluntary death of suicide leads only to natural or bodily death, so it would be more legitimate to consider this kind of death only as a form of natural or bodily death. 
a completely rational choice. Purification is a process that goes on as far as possible and no philosopher would be willing to interrupt it, as if he was sure that it had been achieved.

It is for the same reasons that Olympiodorus ${ }^{68}$ emphasizes that "wishing to die" (ethelein apothnèskein) or readiness to die is bound up both with the philosophical or voluntary death, i.e. with the preparation for death, as well as with the bodily death, whereas pursuit of death (epitēdeuein apothnēskein) concerns only the voluntary death. It is perfectly clear that the true philosopher is the same person who rationally chooses to practise dying without wishing to take his own life. Whoever reads Plato's Phaedo and then hurls himself to his death ${ }^{69}$ has understood nothing of the matter.

68 See again n. 2.

${ }^{69}$ See again the reference to the story of Cleombrotus; n. 34, 35, 36. Gertz (2011: 28) points out that by the

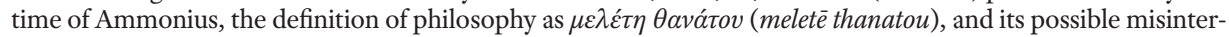
pretation as an exhortation to suicide, had become a standard subject in the introductions to Porphyry's Isagoge. 


\section{REFERENCES}

ArCHER-Hind, R.D., 1894, The Phaedo of Plato, London.

Baltzly, D., 2009, Proclus. Commentary on Plato's Timaeus, Volume IV, Book 3, Part II: Proclus on the World Soul, translated with an introduction and notes, Cambridge.

Bormann, K., 2003 (1973), Platon, Freiburg und München.

Bostock, D., 1986 (repr. 2000), Plato's Phaedo, Oxford.

Brickhouse, T.C. and SMith, N.D., 2010, Socratic Moral Psychology, Cambridge.

Burnet, J., 1911, Plato's Phaedo, edited with introduction and notes, Oxford.

Busse, A. 1891, (ed.), Ammonius, In Porphyrii Isagogen sive V voces, CAG IV3, Berolini.

Chen, L.C.H., 1992, Acquiring knowledge of the Ideas, A Study of Plato's Methods in the Phaedo, the Symposium and the Central Books of the Republic, Stuttgart.

EBERT, T., 2004, Phaidon, Übersetzung und Kommentar, Göttingen.

FreDE, D., 2010 (1999), Platons >Phaidon<. Der Traum von der Unsterblichkeit der Seele, Darmstadt.

Gallop, D., 1975, Plato, Phaedo, Translation with Notes, Oxford.

GERTZ, S.R.P., 2011, Death and Immortality in Late Neoplatonism, Studies on the Ancient Commentaries on Plato's Phaedo, Leiden and Boston.

HaCkforth, R., 1955, Plato's Phaedo, translated with introduction and commentary, Cambridge.

Jowet, B., Plato: Phaedo, translated with an introduction, Oxford (web edition).

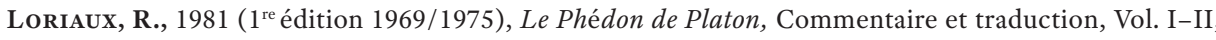
Gembloux.

Plato I, Euthyphro - Apology - Crito - Phaedo - Phaedrus, transl. H.N. Fowler, Cambridge and London.

Rowe, C.J., 1993, Plato. Phaedo, Cambridge.

SEDley, D., Long, A. 2011, (eds.), Plato: Meno and Phaedo, Cambridge.

WARren, J., 2001, “Socratic Suicide”, The Journal of Hellenic Studies 121, pp. 91-106.

WesterinK, L.G., 1956, Olympiodorus: Commentary on the First Alcibiades of Plato, Amsterdam.

Westerink, L.G., 2009 (1976), The Greek Commentaries on Plato's Phaedo, I Olympiodorus, II Damascius, Westbury.

White, F.C., 2006, “Socrates, Philosophers and Death: Two Contrasting Arguments in Plato's Phaedo", The Classical Quarterly 56, pp. 445-458.

MELINA G, MOUZA LA /Patras /
Olympiodorus and Damascius on the Philosopher's Practice of Dying in Plato's Phaedo

This paper presents Olympiodorus' and Damascius' explanations of the philosopher's practice of dying in Plato's Phaedo. It also includes a presentation of Ammonius' exegesis of the practice of death (melete thanatou). The Neoplatonic commentators discern two kinds of death, the bodily or physical death and the voluntary death. Olympiodorus suggests that bodily death is only an image of voluntary death and cannot be recognized as an original death, because original death 
presupposes the preparation for death and the constant effort for the purification of the soul during the philosopher's life-time. Only preparation for death and purification can ensure the complete separation of the soul from the body. Relative to this distinction is that between apothneskein and tethnanai; these infinitives denote the dual meaning of death: death as an event or a process and death as a state. Our study examines thoroughly the subtle distinctions made by Olympiodorus and Damascius and offers a comparative analysis of the two definitions of death as well as that of purification. It reaches the conclusion that apothnēskein is a necessary condition of tethnanai, i.e. of a definitive release and parting of the soul from the body. On the other hand, the process of eventual purification, a notion which betrays the religious character of purification, can be identified with apothnēskein, which is the practice of dying by the true philosopher. Finally, our study also emphasizes and explains the difference between the voluntary philosophical death and the voluntary unphilosophical suicide; the latter guaranteeing only bodily or physical death. 